\title{
Extraction of Hydroxyapatite from Caprine Bones and its Anti-Bacterial Study
}

\author{
Mujeeb Ur Rehman ${ }^{1 a}$, Ayatullah Qureshi ${ }^{1 b}$, Muhammad Moazam Baloch ${ }^{1 \mathrm{c}}$ \\ RECEIVED ON 08.01.2020, ACCEPTED ON 19.05.2020
}

\begin{abstract}
Bones are mineralized connecting tissues consisting of $70 \%$ of Hydroxyapatite (HAP); it is the major component of the bone. Hydroxyapatite (HAP) is most important biomaterial possessing all distinguish features such as antibacterial activity, bioactive and non-inflammatory behavior. Hydroxyapatite is mainly synthesized by two routes i.e. i) using inorganic substances and ii) by exploiting natural sources. The aim of this study is to extract hydroxyapatite using solid waste (animal bones) and to investigate its antibacterial activity. The extraction consisted of alkaline technique and calcination methods. During alkaline process bones became very soft and were easily converted into powder using mortar and pestle without utilizing any milling process and anti-bacterial response was higher when compared to previous studies. The characterization techniques that were utilized are; X-Ray Diffraction (XRD), Fourier Transformed Infrared Spectroscopy (FT-IR) and SEM (Scanning Electron Microscopy (SEM) in order to reveal phase composition, functional groups and surface morphology of HAP. Antibacterial activity was checked by zone of inhibition.
\end{abstract}

Keywords: Hydroxyapatite, alkaline method, zone of inhibition, E.Coli (Escherichia coli)

\section{INTRODUCTION}

$\mathrm{B}$ ones are mineralized connecting tissues consisting of 20-30 $\mathrm{Wt} \%$ organic phase, $60-$ $70 \%$ is inorganic phase and around 5\% consist of water [1]. The organic phase mostly consists of collagen, in addition to proteins, carbohydrates, lipids etc. that are also present in small concentration. A combination of both hydroxyapatite and collagen provides stiffness and mechanical properties to the bone. A model component present in bone is hydroxyapatite [2]. Hydroxyapatite having formula $\mathrm{Ca}_{10}\left(\mathrm{PO}_{4}\right)_{6}\left(\mathrm{OH}_{2}\right.$ is bioactive ceramic material that belongs to calcium phosphate family [3]. The composition and biological structure of Hydroxyapatite resembles to natural bone mineral component. Natural HAP is one the most important biomaterial possessing all distinguish features, such as bioactive, non-inflammatory, non-toxic, osteoconductive, non-immunogenic and anti-bacterial property [2]. Due to these distinctive features, it appeals to the researcher to use it variety of biomedical applications as well as water treatment to disinfect bacteria [4].

Several techniques are utilized to extract or prepare the HAP. For example, it may be synthesized from inorganic substances such as Chemical precipitation method [5], Hydrothermal [6], Sol-Gel [7], Mechanochemical synthesis[8], Micro emulsion[9], and Ultrasonic irradiation method [10]. However high cost and biological unsafe, toxic byproducts are the main problem occurred during synthesizing of HAP from inorganic components [11]. HAP can be extracted from natural sources such as mammalian bones (bovine, caprine, camel, horse) [12-14] marine

${ }^{1}$ Department of Metallurgy and Materials Engineering, Mehran University of Engineering and Technology, Jamshoro, Sindh, Pakistan. Email: 11mt52@student.muet.edu.pk (Corresponding Author), ayat.qureshi@faculty.muet.edu.pk, mozam.baloch@ faculty.edu.pk

This is an open access article published by Mehran University of Engineering and Technology, Jamshoro under CC BY 4.0 International License. 
sources (fish scale and fish bones) [14,15], shell sources (egg shell, sea shell, and cockle) [16, 17] and mineral source (limestone) [18] by many extraction methods such as alkaline hydrolysis [19], hydrothermal [6], thermal decomposition and vibromilling method [5] to remove organic substances to avoid infections and disease transmission during implantation. Naturally extracted HAP is biologically safe and economic[11].

Pathogenic microorganisms are harmful for human health and can be cause of diseases. Micro-organism can be transferred in human body by various sources. Polluted water causes many diseases and infection [20], on the other hand dental implant and bone substitute implants can also lead bacterial diseases [21]. It is found in literature that hydroxyapatite can be used to disinfect bacteria [22, 23]. It is reported that mostly hydroxyapatite are obtained by chemical reactions are used in water treatment [24]. Chemically synthesized methods are often complex and costly [11]. In previous studies the chemically synthesized hydroxyapatite was used to observed antibacterial activity, but the procedures of chemically synthesized HAP are complex and not economical. In this research HAP was obtained by natural source (Solid waste, animal Bones), simple and cost effective procedure was followed by using alkaline technique and calcination methods. The antibacterial performance of naturally extracted HAP was investigated through zone of inhibition.

\section{EXPERIMENTAL WORK}

\subsection{Materials}

Caprine bones were obtained from the local slaughter house of Hyderabad, Sindh. Acetone $\left(\mathrm{CH}_{3} \mathrm{COCH}_{3}\right.$, $99.5 \%)$, Sodium hydroxide $(\mathrm{NaOH}, 99.0 \%)$, hydrogen peroxide $\left(\mathrm{H}_{2} \mathrm{O}_{2}, 30.0 \%\right)$, Eosin methylene blue agar (EMB) were purchased from local market and all were of analytical grade. Deionization water (DI) were used throughout the research work.

Table 1 shows all the chemicals and materials which were used in this research. Fig. 1 shows the flow chart of the process and Fig. 2 shows the pictorial representation of the process.

\begin{tabular}{|c|c|c|}
\hline \multicolumn{3}{|c|}{$\begin{array}{c}\text { Table 1: The list of materials and chemicals that } \\
\text { are used in the process }\end{array}$} \\
\hline S.No & Materials/ Chemicals & $\begin{array}{l}\text { Purity Level } \\
\qquad(\%)\end{array}$ \\
\hline 1 & Acetone & $99.5 \%$ \\
\hline 2 & Hydrogen peroxide & $30.0 \%$ \\
\hline 3 & Sodium Hydroxide & $99.0 \%$ \\
\hline 4 & $\begin{array}{l}\text { Eosin methylene blue } \\
\text { agar }\end{array}$ & - \\
\hline 5 & Bones & - \\
\hline 6 & DI water & - \\
\hline
\end{tabular}

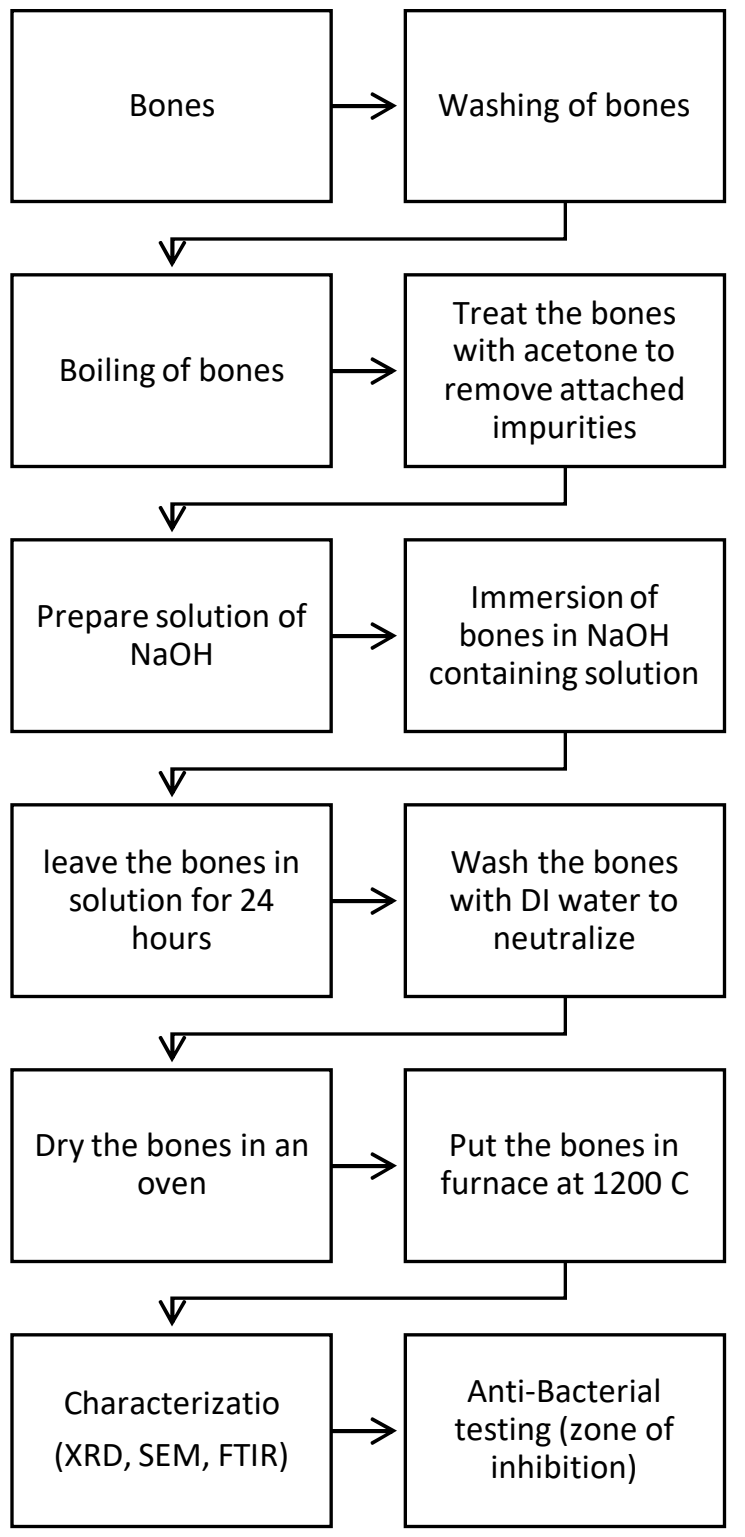

Fig. 1: Complete flow chart of the process 


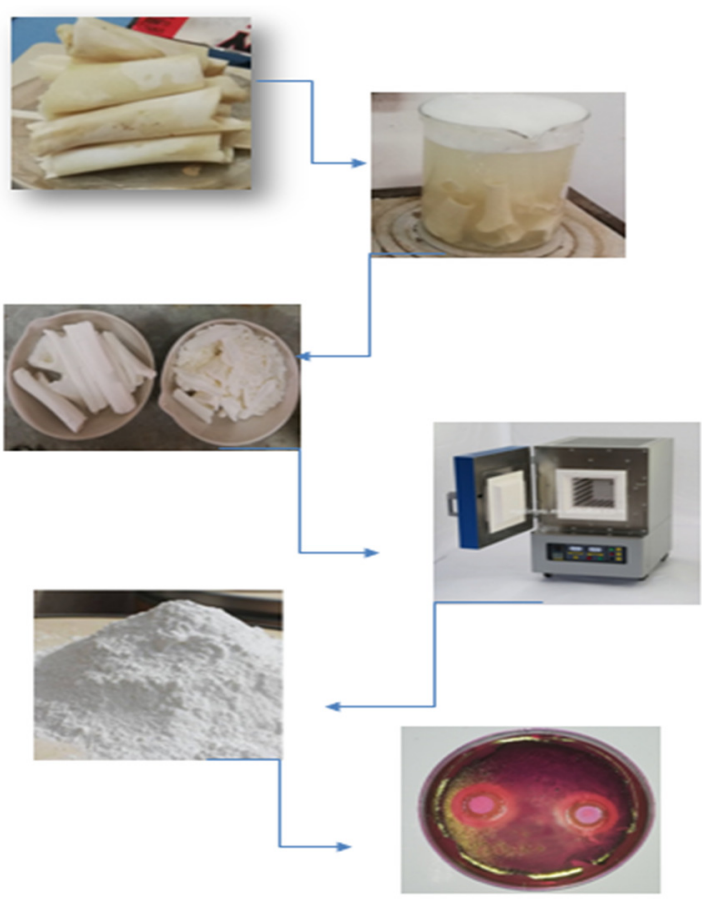

Fig. 2: shows the pictorial representation of the complete process

\subsection{Methods}

\subsubsection{Cleaning}

First of all, bones were washed thoroughly with tap water for several times and boiled for 3-5 hours for removing of muscular attachments. Then bones were treated with solution of acetone and sodium hydroxide for further removing of any attached impurities.

\subsubsection{Alkaline method}

A solution containing $10 \%$ of $\mathrm{NaOH}$ was prepared for the immersion of bones. Bones were immersed in a solution for one day. After that bones were washed several times with distilled water to maintain its $\mathrm{pH}$ as a neutral before calcination. After chemical treatment bones had become very soft and these were easily converted into powder form without utilizing any milling process.

\subsubsection{Calcination}

The bone powder was then calcined in electric muffle furnace at $1200^{\circ} \mathrm{C}$ and holding time was 5 hours to obtain hydroxyapatite.

\section{RESULTS AND DISCUSSIONS}

\subsection{Fourier Transform Infrared (FTIR) technique analysis}

Fourier transform infrared was used to find the presence of functional groups. Potassium bromide $(\mathrm{KBr})$ was utilized for the analyzing. Bone sample and $\mathrm{KBr}$ was mixed with the ratio of $1: 10$ and grinded thoroughly with the help of mortar and pestle. Hydraulic press was used to form transparent disk of mixed material and it was scanned for analyzing the functional groups.

Fig. 3 shows the FTIR graph. In FTIR analysis, the bands at $1000-1100 \mathrm{~cm}^{-1}$ and $560-609 \mathrm{~cm}^{-1}$ were identified as phosphate group. The strongest ranges of phosphate group are 1043 and $609 \mathrm{~cm}^{-1}$, found by Barakat [25]. The bands at $1460-1530$ and $870-880$ were identified as carbonate group. Hosseinzadeh [26] also found that carbonate group have intensive peak at 1417 and $873 \mathrm{~cm}^{-1}$. The absorption bands within $3456-3775 \mathrm{~cm}^{-1}$ are due to O-H ion. In FTIR spectra, in the region within 1500 to $3000 \mathrm{~cm}^{-1}$, there is no intensive peak which indicates that there is complete removal of organic components during chemical immersion of bones.

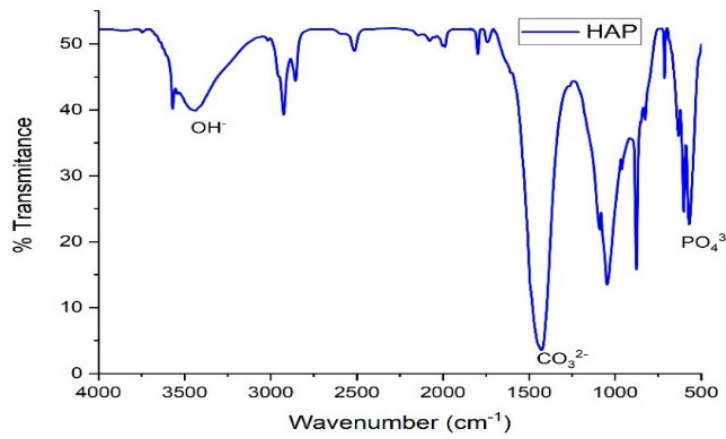

Fig. 3: IR spectrum of prepared HAP Powder

\subsection{X-Ray diffraction (XRD)}

X-Ray diffraction (Model: Bruker-X8) was used to analysis the phase identification and crystallinity of the prepared HAP. XRD source of $\mathrm{Cu} \mathrm{K} \alpha$ radiation with a wavelength of $0.154 \mathrm{~nm}$ geometry was used in this analysis. Samples were scanned from the diffraction angle 20-45 with scanning speed of $2 / \mathrm{min}$ by using of current $40 \mathrm{kV}$. A file standard diffraction 
00-009-0432 was used to compare for identifying the phases of HAP.

Fig. 4 shows the XRD results of prepared hydroxyapatit; Characteristic peak of Hydroxyapatite [13]. The result indicates the keen spectrum of HAP that match with standard (JCPDS card No.09-0432). The three main peaks having high intensity were observed at $\left(31.8^{\circ}, 32.2^{\circ}, 32.9^{\circ}\right)$ associated with the planar hkl (211), (300) and (112) are hydroxyapatite, which were confirmed by comparison study obtained with the Powder Diffraction File (PDF) pattern 090432. The low intensity of the peaks can be attributed to an emerging crystallization and also ascribed to small size of particles.

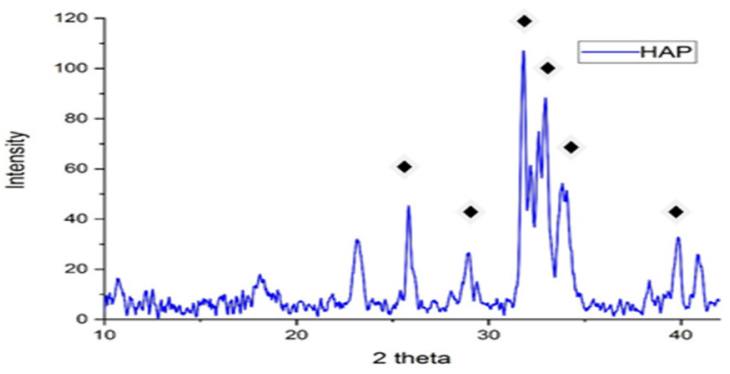

Fig 4: XRD of prepared HAP

\subsection{Scanning Electron Microscopy (SEM)}

Scanning Electron Microscopy (SEM) JEOL JSM 6380_L model was used to study the surface morphology and crystal size of the HAP samples. The samples were coated with gold to give conductivity and protection from the beam damage.

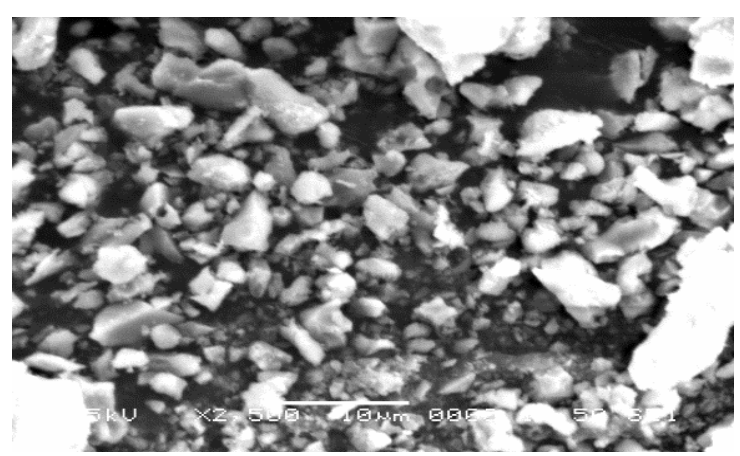

(a)
Fig. 5 reveals the Scanning Electron Microscopy (SEM) results of prepared hydroxyapatite. SEM determines the surface morphology and particle size of HAP extracted from caprine bone. SEM graph shown that particles had non uniform shapes including small spheres and agglomerated in some areas. It was observed that the particles were swelled up because of molar concentration of $\mathrm{NaOH}$.

\subsection{Anti-bacterial study}

Anti-bacterial activity of naturally extracted HAP disk was studied by using disk diffusion method. Following standard procedure, for the cultivation of microorganism, EMB (Eosin methylene blue) agar was poured and evenly distributed into Petri plates. E. coli (Escherichia Coli, KCCM 40880, gram negative) that was incubated in tryptic soy broth for 24 hours at $30{ }^{\circ} \mathrm{C}$ was spread into nutrient containing plates by spread plate method. 2 disc samples of $10 \mathrm{~mm}$ diameter were prepared by using hydraulic press. The produced HAP discs was placed into the Petri plate and incubated at $30{ }^{\circ} \mathrm{C}$ for 24 hours. After that clear area around the disc was studied and measured by ruler.

\subsubsection{Anti bacterial response (Zone of inhibition)}

The result of antibacterial bacterial activity is shown in Fig. 6. The clear area around the HAP disc shows the antibacterial activity. The zone of clear area was measured by ruler [27]. The diameter of clear zone around the disc was $25 \mathrm{~mm}$.

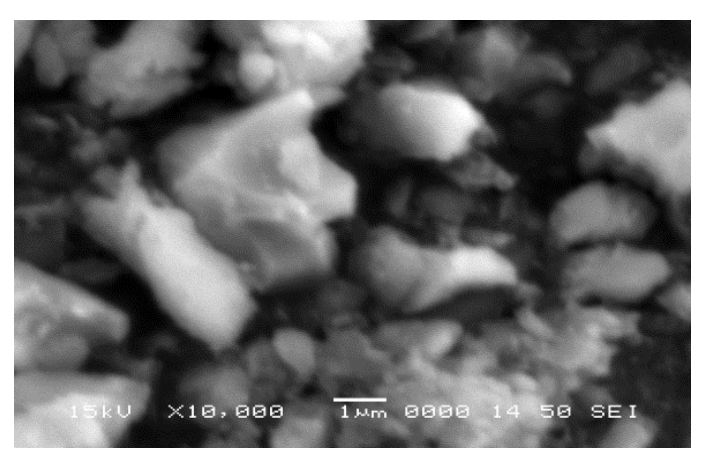

(b)

Fig. 5: Surface Morphology prepared HAP Powder: (a) Magnification of $\times 2500$ (b) Magnification of $\times 1000$

Mehran University Research Journal of Engineering and Technology, Vol. 40, No. 4, October 2021 [p-ISSN: 0254-7821, e-ISSN: 2413-7219] 


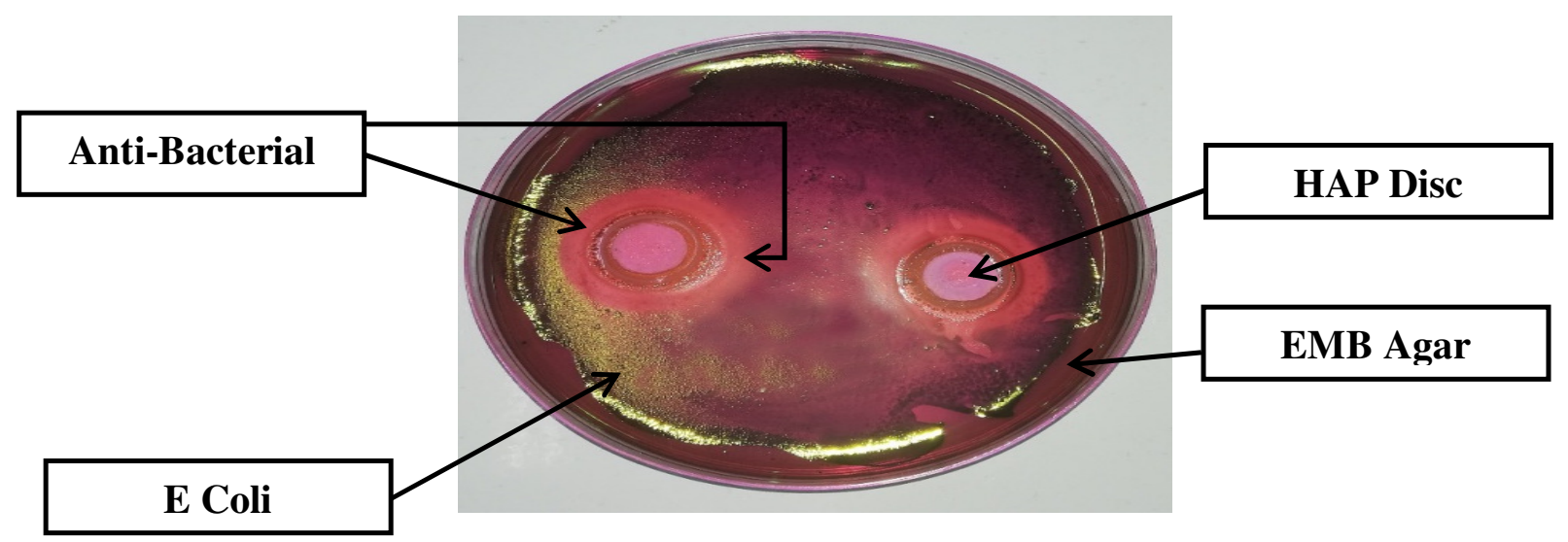

Fig. 5: Shows the anti-bacterial response of prepared HAP

\section{CONCLUSIONS}

An experimental study was carried out to prepare the HAP using natural method. On the basis of this study, it can be concluded that hydroxyapatite was successfully extracted from caprine bone using alkaline method. It is found that the process for the extraction of HAP is simple and cost effective. Antibacterial activity was determined by zone of inhibition; the diameter of clear zone was $25 \mathrm{~mm}$ thereby indicating the antibacterial activity of HAP. An improved response of anti-bacterial activity was observed than that of previous study.

\section{ACKNOWLEDGEMENT}

The authors would like to thanks the department of Metallurgy and Materials Engineering and US Pakistan Centre for advanced studies in water (USPCAS-W) of Mehran University of Engineering and Technology, (MUET) Jamshoro for providing their guidance and lab facilities.

\section{REFERENCES}

1. Florencio-Silva R., da Silva Sasso G.R., SassoCerri E., Simões M. J., Cerri P. S., "Biology of Bone Tissue: Structure, Function, and Factors That Influence Bone Cells", BioMed Research International, Vol. 2015, pp. 1-17, 2015.

2. Bano N., Adzila S., Jikan S. S., Basri H., Kanasan N., "Extraction of Biological Apatite from Cow Bone at Different Calcination Temperatures: A
Comparative Study," Key Engineering Materials, Vol. 796, pp. 46-52, March 2019.

3. Ohtsuki C., Kamitakahara M., Miyazaki T., "Bioactive ceramic-based materials with designed reactivity for bone tissue regeneration," Journal of the Royal Society Interface, Vol. 6, No. Suppl_3, June 2009.

4. Chen W., Oh S., Ong A.P., Oh N., Liu Y., Courtney S.H., Appleford M., Ong J.L., "Antibacterial and osteogenic properties of silvercontaining hydroxyapatite coatings produced using a sol gel process," Journal of Biomedical Research Part A., Vol. 82A, No. 4, pp. 899-906, September 2007.

5. Joshi P., Patel C., Vyas M., "Synthesis and characterization of hydroxyapatite nanoparticles by chemical precipitation method for potential application in water treatment", Proceedings of the International Conference on Nanomaterials for Energy Conversion and Storage Applications, Gujarat, India, 2018.

6. Earl J. S., Wood D. J., Milne S. J., "Hydrothermal synthesis of hydroxyapatite," Journal of Physics Conference Series, Vol. 26, pp. 268-271, Febuary 2006.

7. Yusoff Y. M., Salimi M. N. A., Anuar A., "Preparation of hydroxyapatite nanoparticles by sol-gel method with optimum processing parameters", AIP Conference Proceedings, May 2015.

8. Chaikina M.V., Bulina NV., Ishchenko A.V., Prosanov I.Y., "Mechenochemical Synthesis of Hydroxyapatite and its modifications: Composition, Structure and Properties", Russain 
Physics Journal, Vol. 56, No. 10, pp. 1176-1182, February 2014.

9. Lim G. K., Wang J., Ng S. C., Chew C. H., Gan L. M., "Processing of hydroxyapatite via microemulsion and emulsion routes," Biomaterials, Vol. 18, No. 21, pp. 1433-1439, November 1997.

10. Rouhani P., Taghavinia N., Rouhani S., "Rapid growth of hydroxyapatite nanoparticles using ultrasonic irradiation", Ultrasonic Sonochemistry, Vol. 17, No. 5, pp. 853-856, June 2010.

11. Oktar F.N., Yetmez M., Gundus O., "EditorialNovel Hydroxyapatite (Ha) Production from Synthetic and Natural Sources", Bioceramics Development and Applications, Vol. 7, No.1, pp. 1., 2017.

12. Khoo W., Nor F. M., Ardhyananta H., Kurniawan D., "Preparation of Natural Hydroxyapatite from Bovine Femur Bones Using Calcination at Various Temperatures," Procedia Manufacturing, Vol. 2, pp. 196-201, 2015.

13. Jang K.-J., Cho W.J., Seonwoo H., Kim J., Lim K.T., Chung P.-H., "Development and Characterization of Horse Bone-derived Natural Calcium Phosphate Powders", Journal of Biosystems Engineering, Vol. 39, No. 2, pp. 122133, June 2014.

14. Dabiri S. M. H., Rezaie A. A., Moghimi M., Rezaie H., "Extraction of Hydroxyapatite from Fish Bones and Its Application in Nickel Adsorption", Bio Nano Science, Vol. 8, No. 3, pp. 823-834, Sep. 2018.

15. Muhammad N., Gao Y., Iqbal F., Ahmad P., Ge R., Nishan U., Rahim A., Gonfa G., Ullah Z., "Extraction of biocompatible hydroxyapatite from fish scales using novel approach of ionic liquid pretreatment", Separation and Purification Technology, Vol. 161, pp. 129-135, March 2016.

16. Saharudin S. H., Shariffuddin J. H., Ismail A., "Synthesis of Hydroxyapatite from Cockle Shell Wastes", Materials Today: Proceedings, Vol. 19, No.4, pp. 1208-1215, 2019.

17. Pandharipande S. L., Sondawale M. S. S., "Synthesis of Hydroxyapatite from egg shell and preparation of bone like Bio-composites using it", International Journal of Advanced Science and Technology, Vol. 5, No.8, pp. 36-47, 2016.

18. Habibie S., Wargadipura A.H.S., Gustiono D.,
Herdianto N., Riswoko A., Nikmatin S., Clarke S., "Production and Characterization of Hydroxyapatite Bone Substitute Material Performed from Indonesian Limestone", International Journal of Biomedical Engineering and Science, Vol. 4, No. 1, pp. 11-23, January 2017.

19. Venkatesan J., Qian Z. J., Ryu B., Thomas N. V., Kim S. K., "A comparative study of thermal calcination and an alkaline hydrolysis method in the isolation of hydroxyapatite from Thunnus obesus bone", Biomedical Materials, Vol. 6, No. 3, June 2011.

20. Pandey P. K., Kass P. H., Soupir M. L., Biswas S., Singh V. P., "Contamination of water resources by pathogenic bacteria", $A M B$ Express, Vol. 4, No. 1, December 2014.

21. Ribeiro M., Monteiro F. J., Ferraz M. P., "Infection of orthopedic implants with emphasis on bacterial adhesion process and techniques used in studying bacterial-material interactions," Biomatter, Vol. 2, No. 4, pp. 176194, October 2012.

22. Liao J., Mo A. C., Wu H. K., Zhang J. C., Li Y. B., Lv G. Y., "Antibacterial Activity of SilverHydroxyapatite/Titania Nanoparticles on Oral Bacteria", Key Engineering Materials, Vol. 330-332, pp. 299-302, February 2007.

23. Ahmed M. K., Mansour S. F., Mostafa M. S., Darwesh R., El-dek S. I., "Structural, mechanical and thermal features of $\mathrm{Bi}$ and $\mathrm{Sr}$ co-substituted hydroxyapatite", Journal of Material Science, Vol. 54, No. 3, pp. 19771991, Febuary 2019.

24. Seyedmajidi S., Rajabnia R., Seyedmajidi M., "Evaluation of antibacterial properties of hydroxyapatite/bioactive glass and fluorapatite/bioactive glass nanocomposite foams as a cellular scaffold of bone tissue", Journal of Laboratory Physicians, Vol. 10, No. 3, pp. 265-270, 2018.

25. Brakat N. A. M., Khalil K.A., Sheikh F.A., Omran A.M., Gaihre B., Khil S.M., Kim H.Y., "Physiochemical characterizations of hydroxyapatite extracted from bovine bones by three different methods: Extraction of biologically desirable HAP", Material Science 
and Engineering C, Vol. 28, No. 8, pp. 13811387, December 2008.

26. Hosseinzadeh E., Davarpanah M., Nemati N.H., Tavakoli S. A., "Fabrication of a hard tissue replacement using natural hydroxyapatite derived from bovine bones by thermal decomposition method", International Journal of Organ Transplantation Medicine, Vol. 5, No. 1, pp. 2331, 2014.
27. Hudzicki J., "Kirby-Bauer disk diffusion susceptibility test protocol", American Society for Microbiology, December 2009. 